\title{
The Specter of Black Fatherhood in 12 Years $A$ Slave
}

\author{
Amy Tahani-Bidmeshki, PhD
}

Dedicated to Eric Garner and his daughter, Erica Garner, and their progeny.

\section{Introduction}

Less than a year after the release of Steve McQueen's "12 Years A Slave," Eric Garner, a father of six children and grandfather of three with an additional grandson born after his murder, was choked to death on July 17, 2014 in Staten Island, New York by a police officer who alleged Garner was illegally selling cigarettes. Unarmed, Garner's untimely and unjustified death mobilized thousands of people to demand answers and accountability from law enforcement, and his last words, "I can't breathe" became a rallying cry in the Black Lives Matter (BLM) movement. Garner's daughter, Erica, joined forces with BLM, whose mission includes an end to police violence. On the BLM website, it states, "Black Lives Matter began as a call to action in response to state-sanctioned violence and antiBlack racism."[1] The work of BLM organizers and activists effectively displays the crisis of state-terror and violence, but Black thinkers and activists were making similar calls since at least 1829. ${ }^{[2]}$ Pre-emancipation Black thinkers recognized the suppression of their humanity evidenced in the emergence of chattel slavery and resisted against this institutionalized form of racism that deemed racially Black people as non-human. Yet, from the early nineteenth through the twenty-first century, the issue of being-human remains in crisis for the Black community in the United States. As of the writing of this piece, 136 Black men have been killed since January 2018 by law enforcement. ${ }^{[3]}$ Therefore, the question of if Black lives can matter in this anti-Black world remains at stake. This essay turns to the interventions of Afro-Pessimism and the narratives of fugitive Black enslaved fathers to unpack the matter(ing) of Black fatherhood.

While Steve McQueen's adaptation of Solomon Northup's Twelve Years a Slave elides and obfuscates the complexities of the literary work, especially the nuanced representations of Black womanhood, ${ }^{[4]}$ one element comes through to the screen as powerfully as it does in the literature: defiance against the U.S.-centered, conventional understanding of Black fatherhood. Whether in the literary narrative or film interpretation, Northup's emotional longing and fugitive status stem from his desire to return to his role as a husband and father as much as his hatred for institutionalized racism. His relentless insistence on his status as a free Black man relies heavily on his identification as a husband and father, with a clear familial lineage tied to a specific place. Importantly, this theme of longing to return to a family as a parent is quite common throughout slave and fugitive narratives by men, ${ }^{[5]}$ which highlights the radical rejection by African American men of white patriarchy's relegation of Black fatherhood.

In "Mama's Baby, Papa's Maybe: An American Grammar Book," Hortense Spillers elaborates on white patriarchy's power to fray Black fatherhood "only and precisely because legal enslavement removed the African-American male not so much from sight as from mimetic view as a partner in the prevailing social fiction of the Father's name, the Father's law."[6] The reference here is to the Lacanian concept of the Name or Law of the Father, which, in pared down terms, supports a heteronormative, upper class, white family structure bound in marriage. This suggests that any other formation results in the inability of the alleged normalization of the child. ${ }^{[7]}$ Spillers' Black feminist thought provides a critical lens into thinking about how Solomon Northup offers a form of fatherhood inassimilable into the Law of the Father specifically because, in the American imagination, Black fatherhood has no symbolic function. David Marriott calls the lack of a symbolic presence "the spooky black" suggesting that despite the structural, 
systemic, and institutional forms of denial and rejection of the Black father, as "spook" he "reveals a connection between race and terror, magic and surveillance, idolatry and power." $[8]$ I will demonstrate that in both the written and filmic versions of 12 Years a Slave, the narrative of the social life of the fugitive Black father is the unsettling and unexpected reality that shocks and stupefies the non-Black, especially white reader and viewer more than the violence of slavery.

Saidiya Hartman reminds us of the impossibility of the non-Black, especially white, reader and viewer knowing the horrors of slavery. She says the non-Black, especially white, witness/spectator cannot emote empathy for the enslaved because "the other's pain is acknowledged to the degree that it can be imagined [and/but] by virtue of

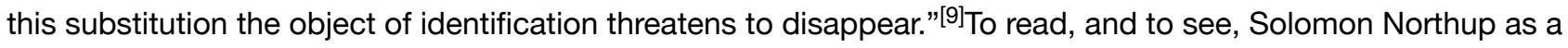
middle-class husband and father simultaneously disrupts stereotypes and allows "enjoyment" (Hartman)for the twenty-first century non-Black viewer. In other words, the non-Black, especially white, person experiences the same response as the white French girl who points at Fanon and exclaims, "Maman, look, a Negro; I'm scared!"[10] As Fred Moten observes, “I don't think these fugitive narratives are about either the glorious entry into subjectivity or about the tragic loss of subjectivity; to place these narratives in that register is already a problem; it liquidates the force that is in the narratives. They are about something else," ${ }^{[11]}$ and I suggest that this "something else" is a fatherhood without the name of the father.

By way of the interventions of Afro-Pessimism, Moten's suggestion highlights that essentially, Black fathers cannot matter, cannot be-human, within the structures of this known world. This does not mean that Black fathers do not exist; instead, this inability to be in this world comes from the condition of "social death" ${ }^{[12]}$ which, as Jared Sexton explains, means "kinship is denied entirely by the force of the law." ${ }^{13]}$ In this known world, the ontological existence of the Black father is illogical, mimetically impossible, in a structure and framework that conditions antiBlackness as requisite to its power. In Northup's narrative, this mimetic impossibility is clear while he is enslaved because as chattel, as non-human, he does not have the ability to position himself as a father. He can produce offspring, but only as property for white men. Yet, even as an unenslaved Black man, his position as a husband, father, and person with agency becomes a social threat, if not a legal one, for white patriarchy.

In both depictions of his experiences, Northup makes clear that white men hunted him: in the north, Hamilton and Brown most likely with the corroboration of other white people in Sarasota Springs, and in the south, the enslavers, their white henchmen, and white women. Therefore, to be a person, a son, a brother, a spouse, a parent/father, is impossible in a world that rejects the Black man's humanity or being-human from its inception. The enslaved father experiences "alienation and isolation [that] is not only vertical, canceling ties to past and future generations [but also] a horizontal prohibition, canceling ties to the slave's contemporaries as well." ${ }^{\text {"14] }}$ As non-Black readers and viewers, the system of slavery and more broadly, the gendered-raced conditions of this known world leave us in awe and terror of the specter of Black fatherhood. We see that there is a "strange freedom in the heart of slavery," [15] a "something else" that is beyond the limitations of white patriarchy and thus, we experience the epistemological and ontological catastrophe that we fear but need for this anti-Black world to be undone.

\section{Years A Slave, the Narrative}

Northup's 12 Years A Slave tells his experiences before and after enslavement, and his narrative exposes the fact that his wife and children and life as a father are the "objet a," ${ }^{[16]}$ the object of desire, that he wants to return to for a sense of wholeness, despite the mechanisms and structures of anti-Blackness that deem his desire impossible. This desire compels him to reject despair in the system of racial slavery, yet Northup's object of desire, fatherhood, functions as a clear marker of impossibility as desires arise from the state of being human, which is specious in the ontological sense for Black men whose function is relegated to white patriarchy's terms. However, in the gaps and spaces that Northup intentionally leaves for the reader, he offers the possibility of imagining liberation away from whiteness's gaze and power.

His narrative begins with his familial lineage: descriptions of geographical locations, occupations, and marital relationships, ${ }^{[17]}$ which decenter the prescriptions of white patriarchy for the Black man because Northup identifies 
the experiences which are akin to white fatherhood. In particular, Northup shares that he and his siblings had a close relationship with their father, a formerly enslaved man who openly discussed his concerns about slavery and the "degradation of his race" with his children. ${ }^{[18]}$ This information allows the non-Black reader to know that this was a priority in their household; however, he does not divulge the specifics of those conversations and keeps private from the non-Black gaze what may have been tactics for survival under white patriarchy and more importantly, plans for another world altogether. Northup deliberately tells the reader that when enslaved men would meet him while accompanying their enslavers, they often "consulted me on the best method of effecting [escape]... and never once, I am proud to say, did I fail to counsel any one (sic) who came to me, to watch his opportunity, and strike for freedom." [19] Here, Northup again reveals to his readers that he is keeping secrets from them. He says that the enslaved sought his advice about attaining freedom, and he "proudly" admits advising them, but knowing that his readers mostly include non-Black people, that is the extent of his descriptions.

Further, Northup's guarded revelations about the conversations among Black folks to a predominately non-Black audience suggest an awareness that "the white externality provided no ontological or ideological certainties; in fact, it explicitly denied slaves the ground for being."[20] If, on the one hand, the slave narrative functioned as a text that evoked affect through graphic details of violence and abuse, religious appeals, and affirmation of white patriarchal values to arouse and encourage the abolition-leaning white audience, ${ }^{[21]}$ the narrative also created spaces of creative thinking about surviving under white domination and thriving through non-white forms of liberation. Returning to the examples of Northup's revelation that his father and he functioned as counselors about life under slavery and methods for survival and escape, the fact stands out that these men were fathers: this parental position is itself a form of anti-white resistance or rejection of whiteness as a structural, systemic, and institutional form of obstruction to Black existence.

This is not to suggest that Black liberation is possible within a world structured on anti-Blackness. As Saidiya Hartman reminds us, "the vexed genealogy of freedom" for the Black person means that, "the advent of freedom marked the transition from the pained and minimally sensate existence of the slave to the burdened individuality of the responsible and encumbered freed person." [22] For Hartman, "burdened individuality" means the dual sense of "being freed from slavery and free of resources, emancipated and subordinated, self-possessed and indebted, equal and inferior, liberated and encumbered, sovereign and dominated, citizen and subject."[23] In other words, in the slave narrative, the discourse centers on demonstrating worthiness of being-human; that is, the ability to choose partners, parenting, relationships, and the other necessary elements of being-human because in the structures of white patriarchy, Black fatherhood cannot exist on the same terms as white fatherhood. As an unenslaved person, the Black father remains under the scriptures of this known world and his so-called freedom remains relegated by white patriarchy.

Black fatherhood challenges the values and mores of paternity, but also, more importantly, infringes on the white man's property rights, thus casting an affront to notions of "being human at all." $[24]$ To echo Wilderson, the Black man cannot claim human-status the way Northup continuously does in his declaration that he is a father and husband because this move decenters white patriarchy, which predicates itself on the subordination of Black men, and so, "violence against Black people is a mechanism for the usurpation of subjectivity, of life, of being."[25] Northup disrupts the narrative of white patriarchy when he claims he feels as free as and equivalent to a white man, but then he is immediately met with violent and brutal blows demanding his subordination. Early in his narrative, he states, "having all my life breathed the free air of the North, and conscious that I possessed the same feelings and affections that find a place in the white man's breast [...] I was too ignorant, perhaps too independent, to conceive how any one (sic) could be content to live in the abject condition of a slave." [26] Northup's possible ignorance or sense of being "too independent" reveal that he is already living beyond the restrictions of white patriarchy, and unsurprisingly, his defiance against the status quo elicits the violence of white masculinity. Spillers names this experience as "certain performances of maleness on the part of the black man [which suggest] that black men can't afford to appropriate the gender prerogatives of white men because they have a different kind of history; so you can't simply be patriarchal. You have to really think about something else as you come to that option."[27] The reader witnesses Northup's refusal of white patriarchy's scripture for Black fatherhood in his nurturing and care 
towards Black enslaved women as he shoulders their pain and consoles them instead of abusing, sexually violating, or even romantically pursuing their companionship. To be sure, Northup contrapuntally receives the wrath of white patriarchy while he lives as the "something else" of this anti-Black world.

Spillers, similar to Moten cited earlier, thinks through Black fatherhood as one of the critical aspects of escaping from the white patriarchal structures of American society. Wilderson calls the forms of Black resistance to white domination "epistemological catastrophe." He says, "Marx posits an epistemological crisis, which is to say moving from one system of human arrangements and relations to another system of human relations and arrangements. What Black people embody is the potential for a catastrophe of human arrangements writ large."[28] For Northup to claim and struggle for a return to fatherhood, paternity, familial heritage, and ties to people who share his lineage is to create an "epistemological catastrophe," as he dismantles the psychic foundations of white patriarchy, which predicates itself on the ontological destruction of the Black person. In other words, the existence of the Black father threatens the being-human of white men and incites the fear of "fall[ing] into the abyss of nonexistence."[29]

The white men who clandestinely kidnapped Northup and drugged him in Maryland with the aim of selling him to enslavers epitomize the white patriarchal fear of the Black free subject. Their act of stalking a free Black father in New York not only demonstrates a complete disregard or more precisely, intentional disruption of the life and family that Northup sustains in Saratoga Springs, but these white men refuse to allow a Black man to assume the position of being-human. The white men force Northup into enslavement, re-name him Platt, deny his life-world, punish him physically for declaring his position as a father and husband. This psychic and physical violence upon Northup signals what Jared Sexton calls "the application of slave law among the free (i.e. the disposition that "with respect to the African shows no internal recognition of the libidinal costs of turning human bodies into sentient flesh"). [30] The rendering of Northup as a father and husband, as an impossible state of being in the world, shows "not a loss (of life and limb, liberty and property), but a never having had." Not only the figurative "nothing to lose but your chains" of the proletariat, but the literal inability to lose (because unable to own, to accumulate, to have and to hold, to self-possess) at all." [31] Yet to consistently break up the Black family, disrupt the progression of ancestral and familial heritages, and dismember the Black body points to the power of the threat posed to whiteness by the social life of the Black community.

Sexton, Moten, and others ${ }^{[32]}$ interrogate the living beyond the institution of slavery and the (im)possibilities of agency in an anti-Black world. Moten's summation that "stolen life disorders positive value just as surely as it is not equivalent to social death or absolute dereliction"[33] applies to Northup's lived experiences as a fugitive Black father. The space between living as un-enslaved but not free and equal and living as enslaved demonstrates an epistemological break, analyzed by Etienne Balibar ${ }^{[34]}$ as suspended knowledges of history, science, experience, which the Black fugitive father carries and which, because of his inability of being-human in the known world, affords him a different experiential ability than the white man. Moten parses this particular positionality and says, "part of what can be attained in this zone of unattainability, to which the eminently attainable ones have been relegated, which they occupy but cannot (and refuse to) own, is some sense of the fugitive law of movement that makes black social life ungovernable, that demands a para-ontological disruption of the supposed connection between explanation and resistance."[35] The silence in Northup's narrative about his relationships with other enslaved people reveals this suspended knowledge and experience. For instance, while the reader learns about his care for Patsy and Eliza, there is no mention of any amorous relationships or sexual encounters. Aside from the fact that as a genre, the slave narrative usually refrains from explicit details of sexuality unless they relate to violence and abuse, this avoidance could mean that those types of bonds were missing from Northup's enslaved experiences, or, he refuses to divulge for the non-Black reader these other possible formations of kinship and love.

Further still, while the parameters of this essay do not allow for a nuanced study, it is critical to note that, "dissemblance is an effective way to understand how Black women [and men] obscure the details of their sexual lives from the historical record." [36] This "obscuring" or rejection of full disclosure of the suspended life of the enslaved contributes to Black social life beyond enslavement as networks of kinship devoid of bloodlines allow the sustainability of Blackness. Invoking Moten's articulation of Blackness as "the extended movement of a specific upheaval, an ongoing irruption that arranges every line-is a strain that pressures the assumption of the 
equivalence of personhood and subjectivity," ${ }^{[37]}$ then the spaces between Black social death and Black social life are perhaps the epistemological catastrophe that the known world needs. However, whiteness cannot allow this catastrophe because the "slave/non-slave, or the Black/human relation, presents us with a structural dynamic which cannot be reconciled and which does not have a coherent mode of redress." [38] Sexton complicates this notion of possibilities of liberation in the midst of an anti-Black world by suggesting that "there is no outside" because "'the language of race developed in the modern period and in the context of the slave trade' (Hartman 2007: 5). And if that context is our context and that context is the world, then this is the principal insight revealed by the contemporary predicament of freedom: there is no such thing as a fugitive slave." [39] While I agree with Sexton that ultimately this known world is not willing to relent to the being-human of the Black man, I echo Moten to suggest that fugitive fatherhood gives us a glimpse into what the epistemological catastrophe of Black fatherhood produces, which is fatherhood without the law of the father. Importantly, this marker of Black social life, that is, fatherhood, strikes terror in the world of white patriarchy.

\section{Years A Slave, the Film}

In an interview with ITN News, director Steve McQueen discussed how he came across the narrative of Solomon Northup and shared that he was shocked that this man's story was unknown to him. McQueen's admission that he read the book and then decided to make this film because "no one I knew knew this story"[40] reveals that he understands the need to undo the work of erasing Black fatherhood, especially fugitive slave narratives of fathers. Said another way, McQueen works against what Spillers identifies as removing Black fathers from "mimetic view." [41] The cinematic language used by McQueen including close-ups, prolonged frames, and sound bridges holds the nonblack, particularly white viewer accountable for acknowledging their complicity in the brutal relegation of Black fatherhood. As Maurice O. Wallace notes, "Just how black masculine subjectivity constitutes itself relative to the masculine hegemony, in other words, or recognizes black masculine subjects as men, in opposition to the putative sociohistoric record noted by Spillers, is a feat of social and psychic wonder that has yet to be definitively named." "42] Yet, Wallace's work towards "definitively nam[ing]" Black men as being-human remains at stake in McQueen's film as the Black fugitive father in particular, haunts and uplifts, inspires awe and terror, and challenges the viewer to consider if Black fatherhood can matter in the known world.

The film illuminates and obscures the ruptures, breaks, and catastrophes of 12 Years $A$ Slave. Similar to the literary narrative, the film is bookended by Northrup's role as a father and husband, but the overlapping diegeses in the film allow the disruption of whiteness through the unfolding narratives of fatherhood, Blackness, and resistance within the known world. To be sure, McQueen's use of sound bridges, flashback, and prolonged zoomed-in angles, forces the viewer to confront the (im)possibility of Black fatherhood. The opening scene shows a group of Black men standing in a sugar cane field on a plantation listening to orders from a white man. The scene exemplifies how Black enslaved men "have been bound within a system of spectragraphia: the constant framing of their lives, photographically and discursively, within a racialist gaze that denies them a full and complex humanity."[43] McQueen's challenge of showing that Black fathers exist in this anti-Black world marks an important resistance to erasure. However, if as Charles Johnson says, every subject needs an object to have phenomenological relevance, ${ }^{[44]}$ and the subject/human is the white man, then the Black father will never matter as being-human as long as white patriarchy relegates the Black man within its own terms. This is to suggest that the Black father functions as white patriarchy's Other, the object, not subject, upon which white men claim superiority. White patriarchy relegates Black fatherhood by stalling or even more so, deeming impossible the progression of Black people through a chronopolitics of modernity built upon "the social and political construction of time, namely the Western spacetime continuum, or History, relevant because the study of space-time destabilizes teleological prescriptions whereby black being-in-time is illegible and always-already untimely." "45] In other words, Solomon Northup as a father creates not only discomfort for the non-Black viewer, but an affective impossibility because non-Black, particularly white, people restrict viewing Black fathers as being-human in this anti-Black world.

The (im)possibility of Black fatherhood stems from structural and systemic constructions by whiteness such that while the violence and brutality of the daily life of the enslaved is normalized for non-Black people, Black 
fatherhood, as it is relegated to white patriarchy's terms, remains as the "something else" that white people never have to confront within the anti-Black world. McQueen's film portrays Black fugitivity in the guise of the father to demonstrate that the awe-inspiring horror for the white viewer stems from a confrontation with the Real: ${ }^{[46]}$ that melding of the symbolic and imaginary that supposedly can never occur. Northup as a "free man," wielding the power of paternity, choosing his partner and having children is not a logical impossibility, but an affective one, which bears down on the non-Black/white viewer to face the being-human of the Black man, a fact that is simultaneously horrific and incredible. McQueen challenges the nonblack viewer's assumptions and expectations throughout the film. One of the most poignant moments in which the nonblack, especially white, viewer feels this tension between white supremacist beliefs and Black experience unfolds in the intimacy of an enslaved woman and Northup on the ship. McQueen invokes overlapping diegesis to layer the intense moment of sexual need and emotional desire as the woman uses Northup to satisfy herself; he flashes back to his sexual relationship with his wife. The camera remains focused on Northup's face as his eyes plead to understand the intensity of the short exchange and his gaping mouth suggests a simultaneous arousal and disgust. ${ }^{[4]}$ The viewer, like Northup, is interrupted in this reverie by the woman's audible crying, but the nonblack viewer must confront the consequences of the overlapping diegesis which is to acknowledge the (im)possiblity of Black love, marital fidelity, and beinghuman.

This dissociative experience of the non-Black, especially white, viewer means she cannot replace her gaze with the enslaved; the substitution of the self is with the enslaver. For the white viewer, her "racialist gaze," "this form of looking, $[\ldots]$ haunts $[\ldots]$ not so much the imago spun through with myths, anecdotes, stories, but the shadow or stain that is sensed behind it and that disturbs well-being." ${ }^{[48]}$ The non-Black and particularly white audience watches Northup on the screen with a "racialist gaze" as they are wont to do in the modern era's schema of subjectivity. The white viewer sees him/her/their self through the white enslavers, not as the object, Black father. Therefore, the horror of what the Black viewer sees pivots between "the constant threat of violence (rather than specific acts of violence) and the sense of liminality characterizing black life."[49] For the non-Black, especially white viewer, the specter of Black fatherhood represents "the spook [which] fulfills [a function to] pacify, to humanize the unformed creatureliness floating toward us and whose existence reveals a residue of the human that cannot be incorporated."[50] The structural, systemic, and institutional forms of anti-Blackness inure the white viewer to the brutal attacks and violence of the white enslavers, but the specter of Black fatherhood upon the screen becomes the ontological and epistemological catastrophe of knowing there is a fatherhood beyond the law of the (white) father. Every time Northup speaks about his paternity, white patriarchal structures become dangerously unstable evinced in the variety of ways white enslavers dehumanize him including erasing his past, his lineage, and physically forcing his submission to their will. This means that the Black father must be silenced by any means necessary: (literal) beatings, (symbolic) removal, and (social) death in order for nonblack people to claim being-human.

While the power of McQueen's cinematic representation of Black fatherhood creates this dissonance for the nonBlack, particularly white viewer, as Valerie Smith notes, the scenes of idyllic family life in Saratoga Springs, New York "create a false sense of the security of Northup's position." ${ }^{[51]}$ McQueen depicts Northup's family life through pastel costuming, luxurious accoutrements such as a walking cane and his wife's sunbrella. The scenes when Northup walks through town with his family are warmly lit to emphasize an idyllic life punctured by his jovial greetings towards his white peers. To be so-called free in an anti-Black world means that the Black father maintains a precarious position of authority and self-determination dictated by white patriarchal structures demonstrated in the film through an imitation of whiteness: soft hues, jovial behavior, nonchalance. Early in the film, the viewer glimpses Northup's non-enslaved life through his warmth with his wife and children; his polite exchanges with white people in town; and as a violinist at private parties. However, the ontological non-beinghuman of the Black father remains a critical point of tension as the film flashes back and forth between Northup's pre-enslaved life and conditions as an enslaved person. The full force of this reminder occurs when he locks gazes with an enslaved man accompanying a white enslaver at a local mercantile shop in his hometown. ${ }^{[52]}$ This scene focuses on the two Black men looking at and being seen by each other; the men's faces reveal mutual acknowledgement, wonder, dismay, and disbelief. Their silent affirmations of each other remain under the gaze of 
the white men in the shop as well as the film's audience. In the narrative, Northup tells the reader that he counseled the enslaved who sought his guidance about fugitivity; McQueen leaves the viewer with a deafening silence between the men.

At the end of Black Skin, White Masks, Fanon says, "I am not a prisoner of History. I must not look for the meaning of my destiny in that direction. I must constantly remind myself that the real leap consists of introducing invention into life." In both texts, the reader/viewer is not privy to the Fanonian leap that occurs between the men. ${ }^{[53]}$ The strategic silences, gaps, and evasions mark possibilities beyond this known world, but steer away from non-racially Black people's epistemological knowledges and ontological experiences. As Malaklou describes, "to leap is not to 'intervene' in, 'break' with, or 'punctuate' the force of History, or the timeline of Man; it is to discard with this timeline (all timelines) and its cartographies (all cartographies), charting new flights of departure without the means with which to enact a teleological schema." [54] The men share the "something elses" of fugitivity, not as merely escape from enslavement, which is the embodiment of the force of being rendered to objects, but more so, a parting from the restrictions of white patriarchy and this known world constructed on anti-Blackness.

A counterpoint moment in Northup's enslaved status occurs on the ship when he colludes with other enslaved men to escape from the vessel. ${ }^{[55]}$ The contentious space of the slave ship, which poses threats to the well-being of the Black bodies it transports, fosters particularly palpable antiblackness for the audience. McQueen employs the cinematic language of antiblackness through dimly lit passages and galleys; moaning, naked Black bodies squirming and writhing in agony, or pleasure; and white enslavers who ubiquitously humiliate, torture, and sexually terrorize the captives. These stereotypical scenes of Black (social) death are punctured when McQueen allows the audience to eavesdrop on the conversations about escape between Northup and some other men. However, with this racialized gaze upon the Black men, their plans for escape fail and the work of the Fanonian leap remains unknowable for the non-Black audience. Sexton offers this explanation about the conditions of being inside and out. He says, "captivity is always an unsettled condition, open to an outside which it will not know anything and about which it cannot stop thinking, a nervous system always in pursuit of the fugitive movement it cannot afford to lose and cannot live without." ${ }^{[56]}$ Black social life finds its potentiality in the "underground, in outer space, or in the cinematic instance, off screen." ${ }^{[57]}$

\section{Conclusion}

In both narrative and film, Northup never abandons the fact that he is a husband and father. The terror and awe afforded to the non-Black, especially white, reader and viewer of the narrative suggests that this positionality as Black (fugitive) father, who seeks reunification with his family more than to escape the terrors of slavery, yields a force that destabilizes white patriarchy towards the possibility of undoing this anti-Black world. However, the important and necessary interventions of Black thinkers such as Hartman, Spillers, Kay Lindsey, ${ }^{[58]}$ and Tiffany Lethabo King ${ }^{[59]}$ remain imperative points of departure for centering Black family-structures as a Fanonian leap to the "something else" of being human. This is to suggest that if within this anti-Black world, the heteronormative Black family is affectively impossible and illogical, no other formations will ever move towards (becoming) human. To remove Black social life from History and Humanity, there must be an abolition of the notion of family because of its link to white, heteronormative, and patriarchal structures. King suggests that, "while Black feminist, queer scholarship and creative work have called for a reimagining of the Black family on radically different terms (non partriarchal, egalitarian and queer), they often do not critique the family in ways that draw attention to the violent ways that the family emerges as a category of violent forms of humanism." [60] Thus, it is not enough to re-imagine, but to destroy, demolish, destabilize family altogether, so that the anti-Black world can be undone. Northup's move to redeem a sense of being-human by concretely positioning himself as the father and patriarch of his nuclear family fails to abolish the institution of slavery and, more pointedly, to safeguard him from a tenuous position under white patriarchy. For the non-Black, especially white, reader and viewer of Northup's narrative, his "borrow[ing] institutionality" [61] disrupts a sense of stability and subjecthood, but ultimately, the Black father, even in the guise of (middle-class, heteronormative) Northup, remains captive within white patriarchal society.

As King suggests, "there is possibility and futurity when one is rendered outside of human coordinates."[62] Without 
recognition of gender, kinship, sexuality, and ultimately, subjecthood, the "something else" of being-human affords one other life-worlds, new forms and kinds of relation building and sustaining. However, at the time of writing this article, yet another young Black father was murdered by law enforcement. ${ }^{[63]}$ The matter(ing) of Black fatherhood in this anti-black world, which renders the Black father defunct, immoral, criminal, and affectively unimaginable, remains at stake even as we must think through King's poignant departure to consider "what kind of violence the notion of 'family' can inflict" ${ }^{[64]}$ upon the Black community.

On December 30, 2017, 27-year-old Erica Garner, daughter of Eric Garner and mother to an eight-year-old daughter and four-month-old son, died because of a heart attack. ${ }^{[65]}$ She was an active member of the Black Lives Matter movement and fought tirelessly against police brutality and for her father's humanity. The rendering of the racially Black person to non being-human echoes in the deaths of Eric and Erica Garner. The structures, institutions, and systems of the anti-Black world continue to do their work of creating the social death of the Black person, but "critical and innovative world-making traditions of Black life must envision life outside of the current categories that blunt efforts to re-craft what it means to be human"[66] and that will lead the way and leap.

\section{Notes}

I would like to thank a number of colleagues whose insights, suggestions, and care helped the crafting of this piece: James Ford, M. Shadee Malaklou, Sharla Fett, Daniel Fineman, and Warren Montag. I am always indebted to your support and appreciate the sense of community I feel with all of you.

1. https://blacklivesmatter.com/about/what-we-believe/ Accessed on 2/14/2018.

2. David Walker, Appeal, in Four Articles; Together with a Preamble, to the Coloured Citizens of the World, but in Particular, and Very Expressly, to Those of the United States of America, Written in Boston, State of Massachusetts, September 28, 1829 (Hill and Wang, 1965).

3. This article was written in February 2018. http://killedbypolice.net/

4. 12 Years A Slave. Directed by Steve McQueen. Hollywood, CA: Regency Enterprises, 2013. See Brenda Stevenson, Life in Black and White: Family and Community in the Slave South (Oxford University Press, 1996). Historian Brenda Stevenson offers a nuanced understanding of the lives of the enslaved in Loudoun County, Virginia; and in "12 Years a Slave: Narrative, History, and Film." The Journal of African American History, vol. 19, no. 1-2 (Winter-Spring 2014): 106-118.

5. See also Henry Bibb, Narrative of the Life and Adventures of Henry Bibb, An American Slave and Venture Smith, A Narrative of the Life and Adventures of Venture, a Native of Africa: But Resident above Sixty Years in the United States of America, Related by Himself.

6. Hortense J. Spillers, “Mama's Baby, Papa's Maybe: An American Grammar Book,” Diacritics, vol. 17, no. 2 (Summer 1987): 80.

7. Jacques Lacan, Ecrits: A Selection (W.W. Norton \& Company, 1977). In, "On the possible treatment of psychosis," Lacan states "for the psychosis to be triggered off, the Name-of-the-Father [...] never having attained the place of the Other, must be called into symbolic opposition to the subject" (217). This suggests that the father is critical to warding off mental illness, but Lacan's analysis fails to consider the role of racism in this schema with the systemic, institutional, and structural impediments to black fatherhood.

8. David Marriott, Haunted Life: Visual Culture and Black Modernity (Rutgers University Press, 2007), 1.

9. Saidiya Hartman, Scenes of Subjection: Terror, Slavery, and Self-Making in Nineteenth-Century America (Oxford University Press, 1997), 19. I invoke Hartman's definition and use of the term enjoyment, which she defines as, "to take delight in, to use, and to possess are inextricably linked and, moreover, that enjoyment entails everything from the use of one's possession to the value of whiteness, which can be considered an incorporeal hereditament or illusory inheritance of chattel slavery."

Further, "Empathic identification is complicated further by the fact that it cannot be extricated from the economy of chattel slavery with which it is at odds, for this projection of one's feeling upon or into the object 
of property and the phantasmic slipping into captivity, while it is distinct from the pleasures of selfaugmentation yielded by the ownership of the captive body and the expectations fostered therein, is nonetheless entangled with this economy and identification facilitated by a kindred possession or occupation of the captive body, albeit on a different register." $21,23$.

10. Frantz Fanon, trans. Richard Philcox, Black Skin, White Masks (Grove Press, 2008), 91.

11. Fred Moten, "Black Studies: Grammars of the Fugitive," Goldsmiths College, University of London, December 6, 2013 https://archive.org/details/Blackstudiesgrammarsoffugitive. Emphasis mine.

12. Orlando Patterson, Slavery and Social Death (Harvard University Press, 1982).

13. Jared Sexton, "Curtain of the Sky: An Introduction," Critical Sociology 36 (1), 14.

14. Ibid. 14.

15. Ibid. 17.

16. Jacques Lacan, trans. Alan Sheridan, "The Split Between the Eye and the Gaze," The Four Fundamental Concepts of Psychoanalysis: The Seminar of Jacques Lacan (W.W. Norton \& Company, 1977).

17. Solomon Northup, 12 Years A Slave (Oshun Publishing, 2013). In the first chapter, Northup tells the reader about his family, emphasizing that they are free and have "for more than thirty years enjoyed the blessings of liberty in a free State," 13.

18. Ibid. 15.

19. Ibid.

20. Houston A. Baker, Jr., The Journey Back: Issues in Black Literature and Criticism (Chicago: University of Chicago Press, 1980): 30.

21. John Sekora, "Black Message/White Envelope: Genre, Authenticity, and Authority in the Antebellum Slave Narrative," Callaloo, no. 32 (Summer 1987): 484-513.

22. Hartman, "The Burdened Individuality of Freedom," Scenes of Subjection (Oxford University Press, 1997), 115.

23. Ibid. 116-117, 118. Emphasis mine.

24. Jared Sexton, "The Social Life of Social Death: On Afro-Pessimism and Black Optimism," InTensions Journal, Issue 5 (Fall/Winter 2011): 7.

25. Frank B. Wilderson, III, "Blacks and the Master/Slave Relation," Interview from "Against the Grain," KPFA Radio, Berkeley, California, March 4, 2015. Transcription from the editors of https://belliresearchinstitute.com /2017/02/23/a-very-short-intro, 25.

26. Northup, 20.

27. See Hortense Spillers, Saidiya Hartman, Farah Jasmine Griffin, Shelly Eversley and Jennifer L. Morgan, “'Whatcha Gonna Do?'”: Revisiting 'Mama's Baby, Papa's Maybe: An American Grammar Book'," Women's Studies Quarterly, vol. 35, no. 1/2 The Sexual Body (Spring-Summer 2007): 304. Emphasis mine.

28. Wilderson, "Blacks and the Master/Slave Relation," 30.

29. Ibid., 29.

30. Sexton, "The Curtain of the Sky" 18.

31. Ibid., 16.

32. See Jared Sexton, "The Social Life of Social Death: On Afro-Pessimism and Black Optimism," Fred Moten, "The Case of Blackness," Criticism, vol. 50, no. 2 (Spring 2008): 177-218; Orlando Patterson, Slavery and Social Death; Saidiya Hartman, Lose Your Mother: A Journey Along the Atlantic Slave Route (Farrar, Straus, and Giroux, 2007).

33. Moten, "The Case of Blackness," 187.

34. Etienne Balibar, "From Bachelard to Althusser: the concept of 'epistemological break'," Economy and Society vol. 7, no. 3 (August 1978): 207-237. Balibar traces Althusser's investigation into Bachelard's concept of "epistemological break. Balibar says, "A certain encounter between Marxist philosophy on the one hand and works in the history of sciences and in epistemology on the other has taken place around the category of 'epistemological break' that has been put forward by Louis Althusser," 207. Balibar continues, "the remarkable idea that what characterizes scientific thought is not abstraction as such but on the contrary 
the realization of abstraction in the concrete, the production of 'abstract-concrete' technical objects, concrete in that they incorporate and make objective theoretical abstractions 'function'," 211.

35. Moten, 179.

36. Mattie Udora Richardson, "No More Secrets, No More Lies: African American History and Compulsory Heterosexuality," Journal of Women's History, vol. 15, no. 3 (Autumn 2003), 65.

37. Fred Moten, "Resistance of the Object: Aunt Hester's Scream," In the Break: The Aesthetics of the Black Radical Tradition (University of Minnesota Press, 2003), 1.

38. Wilderson, "Blacks and the Master/Slave Relation," 17.

39. Sexton, "Curtain of the Sky," 16.

40. https://www.youtube.com/watch?v=1JqAsdlz_jw. Minute mark 0:49-0:50. Published on January 8, 2014. [Accessed on 2/8/18].

41. Spillers, "Mama's Baby, Papa's Maybe," 80.

42. Maurice O. Wallace, "Introduction," Constructing the Black Masculine: Identity and Ideality in African American Men's Literature and Culture, 1775-1995 (Duke University Press, 2002), 2.

43. Green, Keith Michael, "Am I Not a Husband and Father? Re-membering Black Masculinity, Slave Incarceration, and Cherokee Slavery in The Life and Adventures of Henry Bibb, an American Slave," MELUS, vol. 29, no. 4 (Winter 2014): 23.

44. Charles Johnson, "A Phenomenology of the Black Body," Michigan Quarterly Review, vol. 32, no.4, 600.

45. M. Shadee Malaklou, "On the Chronopolitics of Black Social Life; or, How Mister Winfield 'Sends Go'," Black Camera, vol. 7, n. 1 (Fall 2015): 219.

46. Here I invoke the Lacanian notion of the Real as explained by Mikkel Borch-Jacobsen to be "pure and simple," "undifferentiated." Mikkel Borch-Jacobsen, Lacan: The Absolute Master, trans. Douglas Brick. (Stanford, CA, 1991). 192.

47. McQueen, minute mark 3:37-6:00.

48. Marriott, "Spooks: Wideman's Catastrophe," 2.

49. Erica Ball, "The Unbearable Liminality of Blackness: Reconsidering Violence in Steve McQueen's 12 Years a Slave," Transition, no. 119, Afro-Asian Worlds (2016): 177.

50. Marriott, "Spooks: Wideman's Catastrophe," 1-2.

51. Valerie Smith, "Life in the Balance: 12 Years a Slave," American Literary History, vol. 26, no.2, 364.

52. McQueen, minute mark 21:33-22:38.

53. Frantz Fanon, trans. Richard Philcox, Black Skin, White Masks (Grove Press, 2008), 204.

54. Malaklou, "On the Chronopolitics," 223-4.

55. McQueen, minute mark 27:22-27:37.

56. Sexton, "The Social Life of Social Death," 28.

57. Ibid. 9.

58. Kay Lindsey, "The Black Woman as Woman," The Black Woman Anthology, ed. Toni Cade Bambara (New American Library, Inc., 1970) argues for the complete abolition of the notion of family. This call comes from considering family as the white, heteronormative, institutional form of claiming humanity and thus, rendering black families as defective, problematic, and outside of the normal.

59. Tiffany Lethebo King, "Black 'Feminisms' and Pessimism: Abolishing Moynihan's Negro Family," Theory and Event, vol. 21, no. 1, (January 2018): 68-87.

60. Ibid., 70.

61. Frank B. Wilderson III, Red, White, and Black: Cinema and the Structure of U.S. Antagonism (Duke University Press, 2010), 127.

62. King, 79.

63. Case of Anthony Weber. http://www.latimes.com/local/lanow/la-me-deputy-teen-shooting-20180209story.html

64. King, 84.

65. https://www.npr.org/sections/thetwo-way/2017/12/30/574514217/erica-garner-who-became-an-activistafter-her-fathers-death-dies 
66. King, 84 .

\section{Cite this Essay}

Tahani-Bidmeshki, Amy. "The Specter of Black Fatherhood in 12 Years A Slave." Rhizomes: Cultural Studies in Emerging Knowledge, no. 35, 2019, doi:10.20415/rhiz/035.e01

RHIZOMES ISSN 1555-9998 $\star 230$ East Hall Bowling Green State University Bowling Green, OH 43403

Editors: Ellen Berry and Carol Siegel. Reviews editor: Craig J. Saper. Technical editor: Helen J Burgess 